\title{
Meat prices influence the consumption of wildlife by the Tsimane' Amerindians of Bolivia
}

\author{
Lilian Apaza, David Wilkie, Elizabeth Byron, Tomás Huanca, William Leonard, Eddy Pérez, \\ Victoria Reyes-García, Vincent Vadez and Ricardo Godoy
}

\begin{abstract}
Wildlife (bushmeat or game) is the primary source of protein for most poor households in tropical forests, and its consumption is resulting in unsustainable hunting of large animals, even in isolated regions. As a result, loss of fauna is often a more immediate and significant threat to the conservation of biological diversity in tropical forests than is deforestation. Although the potential effects of the extirpation from tropical forests of large, seed predating and seed dispersing wild animals is poorly understood, it is likely that there will be irrevocable changes in the structure and function of these ecosystems. We carried out a survey of 510 households of Tsimane' Amerindians in the rainforest of Bolivia to investigate how the prices of game and meat from domesticated animals affect the consumption of
\end{abstract}

game. The results indicated that the price of fish and meat from livestock is positively correlated with consumption of wildlife, suggesting that policy makers may be able to reduce the unsustainable hunting of wildlife for food by reducing the price of fish and the price of meat from domesticated animals relative to that of wildlife. Increasing the production of livestock without causing environmental degradation will require longterm public investment in agricultural research and extension, and substitution of fish for game meat in the absence of sustainable management regimes will result in over-exploitation of riverine and lacustrine fish stocks.

Keywords Bolivia, bushmeat, game, price elasticities, tropical forests, Tsimane' Amerindians, wildlife.

\section{Introduction}

Wildlife is the primary source of animal protein for rural and urban households in most forested regions of poor nations (Redford, 1993; Chardonnet, 1995) and provides higher than average annual incomes to hunters and to many traders (Dethier, 1995; Ngnegueu \& Fotso, 1998). In this paper wildlife refers to terrestrial and aquatic animals other than fish, and game or bushmeat

Lilian Apaza and Eddy Pérez Departamento de Biología, Universidad Mayor de San Andrés, Casilla 10077 - Correo Central Campus Universitario, c/ 27 Cota Cota, La Paz, Bolivia.

David Wilkie (Corresponding author) Wildlife Conservation Society, 18 Clark Lane, Waltham, MA 02451-1823, USA. E-mail: dwilkie@rcn.com

Elizabeth Byron and Victoria Reyes-García Department of Anthropology, University of Florida, Gainesville, Florida 32611, USA

Tomás Huanca Instituto Cultural Aruwiyiri, Casilla 9628, La Paz, Bolivia.

William Leonard Department of Anthropology, Northwestern University, Evanston, Illinois 60201, USA

Vincent Vadez Agronomy Physiology Laboratory, University of Florida, Gainesville, Florida 32611, USA.

Ricardo Godoy Heller School for Social Policy and Management, Brandeis University, Waltham, MA 02454-9110, USA.

Received 29 October 2001. Revision requested 13 May 2002 Accepted 25 July 2002 to species that are hunted for food. Hunting of wildlife for food, rather than habitat loss, is the most significant threat to the conservation of biological diversity in the tropics over the next 15-25 years (Robinson et al., 1999; Wilkie \& Carpenter, 1999). Unsustainable hunting may cause the local or global extinction of species unique to tropical forests (Bodmer et al., 1988; Bodmer et al., 1997; Winterhalder \& Lu, 1997; Barnes, 2002) and the irreversible loss of value these species confer to rural communities and to the world (Bowen-Jones \& Pendry, 1999; Wilkie \& Carpenter, 1999). Moreover, loss of frugivorous species will alter the seed dispersal potential of up to $80 \%$ of the tree species, affecting seed shadows, seed rain, and seedling survival (Peres \& van Roosmalen, 2002). Overexploitation of wildlife species will alter the dominance hierarchies of tree species and forest composition, structure and biomass (Chapman \& Chapman, 1997), and will have unknown impacts on rates of succession, regrowth of fallow fields, accretion of soil nutrients and carbon sequestration. Unsustainable hunting will also result in declines in carnivores, particularly large cats that rely on game species as prey (Hart et al., 1996).

It has been argued that the eating of bushmeat is a deeply rooted cultural preference, and proponents of this theory cite the willingness of some consumers to pay a premium over domestic meat for the pleasure or prestige of eating or serving bushmeat (Rose, 2001). Others have pointed to the important role of bushmeat 
in ceremonies and as a village icon for urban families (ma Mbalele, 1978; Chardonnet et al., 1995; Njiforti, 1996; Trefon \& de Maret, 1999). Yet others believe that consumers respond to price, and typically choose the most affordable meat available in local markets or that which can be harvested free from forests and savannahs (Bowen-Jones, 1998; Wilkie \& Carpenter, 1999; Fa et al., 2000; Wilkie \& Godoy, 2000).

Like most tropical lowland Amerindian populations, the Tsimane' Amerindians of Bolivia practise slash-andburn agriculture and forage for wild plants and game, typically in lands within a radius of about $3 \mathrm{~km}$ from the village. Although largely self-sufficient, the Tsimane' earn cash from selling thatch palm and agricultural goods and from working as unskilled labourers in logging camps, ranches and farms. Chicchón (1992), Ellis (1996), Huanca (2000), Godoy (2001) and Reyes-García (2001) provide ethnographic and historical accounts of the Tsimane'.

One of the largest indigenous groups of lowland Bolivia, the Tsimane' live in the plains and rainforests of the Department of Beni, where they occupy an area of c. 1.2 million ha. They numbered 5,124 in 1995 (Government of Bolivia, 1995) and 7,385 in 1999 (Vice Ministry of Indigenous Affairs, 1999). Until the late 19th century they avoided permanent contact with missionaries, traders and other outsiders (Nordenskiold, 1924; Castillo, 1988; Ellis, 1996), but in the 20th century the Tsimane' started to pan gold, extract quinine, tap rubber, sell rice and pelts, and work as unskilled labourers (Piland, 1991). Contact with outsiders increased from the 1950s onward. The Redemptorist missionaries set up a Catholic mission in the upper reaches of the Maniqui river in 1953 (Ellis, 1996), and Protestant missionaries entered the region in the late 1950s, setting up schools and a clinic, and training many of today's Tsimane' political leaders. Traders from the towns of Yucumo and San Borja started to enter the Tsimane' territory in the 1970s, giving credit and alcohol in exchange for rice and forest goods. Highland colonists also started to settle the area in the 1970s (Riester, 1993). Today, the role of Protestant missionaries as brokers for the Tsimane' has waned, overshadowed by the increasing autonomy of the Gran Consejo Tsimane', the governing body of the Tsimane' people, which the missionaries helped to create in 1989.

Market contact and acculturation into the larger Bolivian society have not resulted in social disorganization, nor have they caused the Tsimane' to take part in messianic movements, as has happened among the neighbouring Mojeño and Yuracaré Amerindians (Riester, 1976; Lehm, 1991). Instead, integration with markets seems to have induced Tsimane' to monocrop, deplete game (Ellis, 1996), reduce the length of fallow, mine the soil (Piland,1991), and sell valuable goods from the forest (Añez, 1992; Rioja, 1992; Gullison, 1995; Howard et al., 1996; Rice et al., 1997). However, the Tsimane' take part in markets in different ways and degrees. Remote villages are inhabited by monolingual speakers of Tsimane' who forage and practise slash-and-burn farming. Their contact with outsiders is limited to bartering rice or palm frond thatch for salt, metal tools and alcohol. Villages closer to towns have access to primary schools with bilingual teachers, and thus many speak Spanish. This combination of proximity to markets and language skills make it easier for them to sell rice and buy commercial goods. From a research perspective, the range of access to markets and of household income among the Tsimane' provides the variance we need to explore how income and meat prices may influence consumption.

Economic theory (Browning \& Zupan, 1999) suggests that consumption changes with the price of goods and the price of close substitutes. Two prices influence the consumption of wildlife: the price of game meat and the price of close substitutes. All else being equal, an increase in the price of game will reduce the consumption of game meat, and vice-versa. This relation is the own-price elasticity of consumption, defined as a percent change in the consumption of game meat brought about by a percent change in the price of game meat. A decrease in the price of another source of animal protein, such as fish or beef, ought to decrease game meat consumption if game meat and meat from livestock or fish are substitutes for each other. The relation between a good and its substitutes is the cross-price elasticity of consumption, defined in this case as the percent change in the consumption of game meat produced by a percent change in the price of another type of animal protein. A negative cross-price elasticity of consumption means the two goods are complements, and occurs when an increase in the price of, say, beef results in a decline in consumption of game meat. A positive cross-price elasticity of consumption implies that the two goods are substitutes, and means, for example, that an increase in the price of beef results in an increase in game meat consumption.

When we refer to price, this does not necessarily indicate that the item was purchased. Price refers to the value attributed to the item by the producer or consumer. All goods produced in Tsimane' villages have value, even if they are not typically sold. For example, if it takes one week to gather the materials and to construct a wicker fish trap, the manufacturer of the trap would typically demand more goods in exchange for the trap than for another 'non-priced' item that only took one day to make. The value or price of the fish trap is reflected in the total price of market goods that the manufacturer would be willing to accept in 
exchange, even when fish traps are rarely if ever traded. By determining the value of market goods with a known price that would be demanded in exchange for a locally produced good we can assess the value of such nonpriced goods. Wildlife hunted by Tsimane' for consumption solely within the hunter's household still has a value because hunting requires expenditure of the hunter's time and the purchase or manufacture of weapons. Hunters clearly value the game they capture because they rarely, if ever, give away game meat without expecting something in return.

In this paper we contribute to the empirical analysis of how household income, and the price of game, fish and meat from livestock, affects choices consumers make about the types of animal protein they consume. For the empirical analysis we use the results of a large crosssectional survey of economic determinants of meat consumption in households of Tsimane' Amerindians in villages in the Department of Beni, in the forested lowlands of Bolivia (Fig. 1).

\section{Methods}

A total of 510 households in 59 Tsimane' villages were surveyed once each between June and November 2000, to collect information on the consumption of the meat of livestock, wildlife and fish, and on socioeconomic covariates of consumption, particularly income and

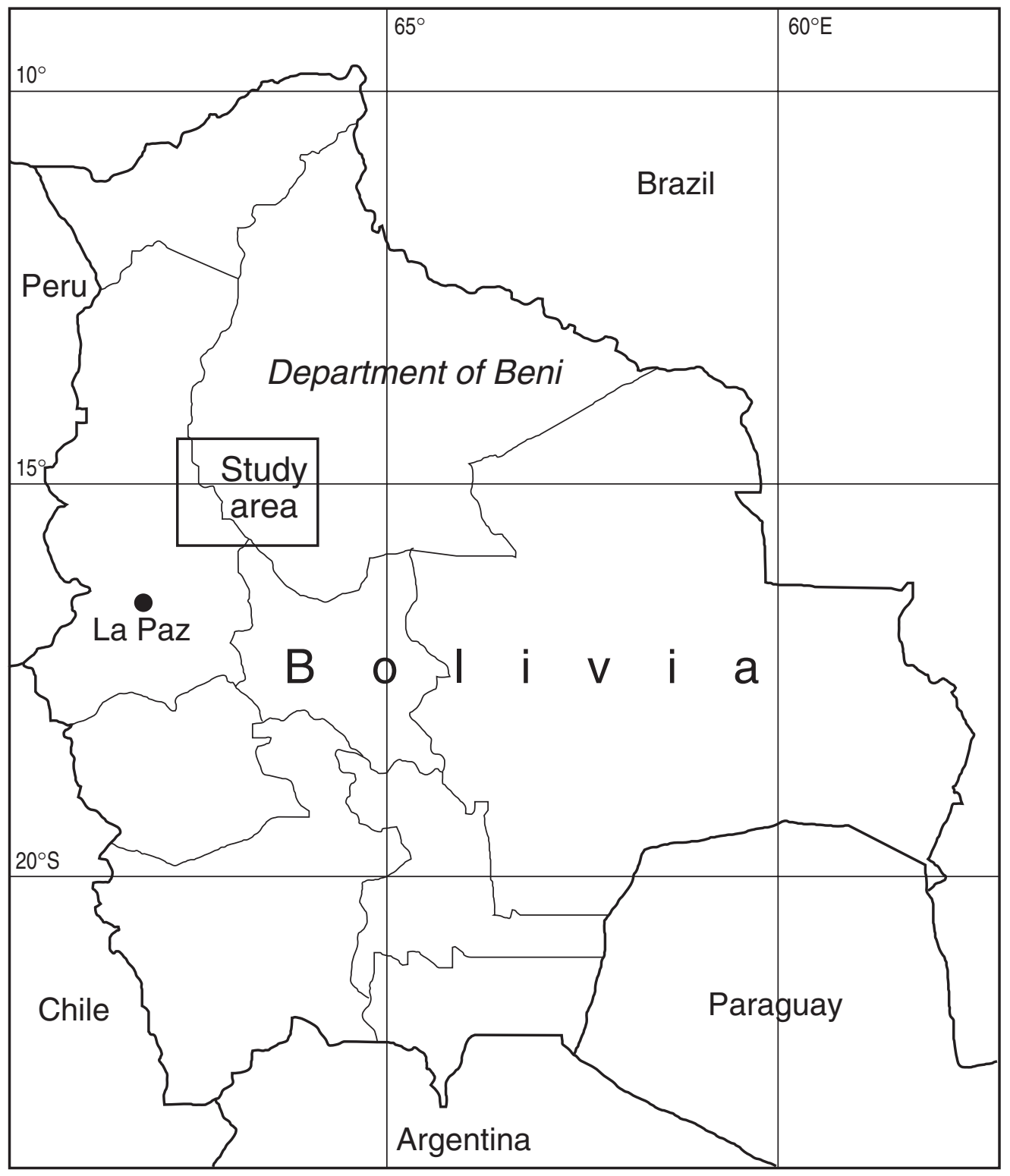

Fig. 1 Location of the study area in the Tsimane' territory within the Department of Beni, Bolivia. 
prices. The design and administration of the household survey benefited from experience gained during a year of fieldwork in two communities: one close (San Antonio) and one far (Yaranda) from the town of San Borja, Department of Beni (Fig. 1), and by a pilot survey conducted between May and June 2000 in a sample of Tsimane' communities close to the town of San Borja.

We selected villages from all the main Tsimane' regions, including the Pilón-Lajas Reserve, Territorio Multiétnico, and Territorio Uno, all in the department of Beni. After completing a village census we randomly selected 7-10 households in each village. We selected at random one of the two household heads to answer the 120 questions in the survey, conducted in Tsimane' and Spanish. According to a census of lowland Bolivian Indians (Government of Bolivia, 1995), 76\% of indigenous households are nuclear, and thus having one of the two household heads answer the survey questions was likely to capture one of the most important decision makers of the household. Dependent variables were the quantity of livestock meat, game meat, and fish consumed by a household in the previous 2 days, expressed as the number of $\mathrm{kg}$ consumed per adult equivalent in the 2 days prior to the survey. Explanatory variables were: (1) the village price of game meat expressed as the average price of collared peccary Tayassu tajacu, agouti Dasyprocta spp. and red brocket deer Mazama americana in Bolivianos per $\mathrm{kg}$, (2) the average village price of three common fish species in Bolivianos per $\mathrm{kg}$, and (3) the village price of beef in Bolivianos per $\mathrm{kg}$. Household income was assessed as the total earnings from wage labour, the sale of goods, and the value of all items obtained through barter in the 2 weeks before the survey. Household wealth was assessed by calculating the total value of a standard set of items owned by the household. These items included modern assets (machete, bicycle, axe, knives, mosquito nets, shotguns, rifles and fish hooks) and traditional assets (canoes, cows, bows, ducks, pigs, hens, woven bags and slingshots). Both income and wealth were expressed in terms of adult equivalents.

Adult equivalents were determined based on estimated daily food energy requirements (kcal per day) of individuals of different age and gender. These energy equirements were calculated using the most recent WHO protocol (James \& Schofield, 1990) and the ageand sex-specific anthropometric data we collected on 1,329 Tsimane' in the Department of Beni. The WHO method determines energy need based on body size and typical activity levels. This approach is preferable to other commonly used methods for determining adult equivalents because it provides an index of relative differences in biological needs, and it reflects the age and sex differences in the particular population being studied. To estimate the number of adult equivalents in a household we multiplied the number of individuals in an age-gender class by the average value for their class ( 0.83 for men, 0.67 for women, 0.55 for boys and 0.52 for girls). All individuals 18 years or older were considered adult.

Additional variables were included to statistically control for household and village attributes: median age and median education level of the adult men in the household, straight-line distance in $\mathrm{km}$ from the village to the nearest commercial town, household size expressed as the total number of adult equivalents, and a separate dummy variable for the villages. Consumption, income, wealth, prices and distance to market were transformed into natural logarithms. To estimate how prices, income and wealth influence meat consumption, ordinary least squares multiple regression with robust standard errors was used to estimate elasticities of consumption (i.e. the regression coefficients). This statistical analysis was carried out using STATA (Stata Corporation, College Station, Texas, USA).

\section{Results}

Summary statistics for the household surveys are given in Table 1. On average Tsimane' eat $475 \mathrm{~g}$ of game meat per adult equivalent per day compared with $310 \mathrm{~g}$ of fish and $250 \mathrm{~g}$ of beef. Fish is the least expensive meat and livestock the most expensive meat.

The price of game meat and its substitutes (fish and beef) influence consumption of game meat (i.e. the own- and cross-price elasticities of demand). The most important finding is the strong influence that the price of beef has on the consumption of game meat and fish, with the regression coefficient indicating that a doubling in the price of beef increases consumption of game meat by $744 \%$ (Table 2), and increases consumption of fish by $133 \%$. A doubling in the price of fish increases consumption of game by $146 \%$.

The consumption of beef and game meat, but not of fish, respond to their own prices (Table 2). A doubling in the price of game meat reduces its consumption by $114 \%$ and a doubling in the price of livestock reduces consumption of beef by $382 \%$. Income and wealth appear to play a minimal and mostly statistically insignificant role in the consumption of game meat, fish and beef (Table 2).

\section{Discussion}

The population of Bolivia has grown from 1.3 million in 1830 to over 8 million in 2000 (Universiteit Utrecht, 2002), and the data collected during our censuses suggest that the Tsimane' population is increasing at $4.8 \%$, 
Table 1 Mean and standard deviation of the consumption and price of game meat, fish and livestock meat, and attributes of individual households (number of adults, income and wealth) and villages (distance to nearest town), and median age and years of education of adult men, derived from a survey of a total of 510 Tsimane' households in 59 villages in 2000. See text for explanation of units.

\begin{tabular}{lrrl}
\hline Variable & Value & SD & Units \\
\hline Game meat consumption (in last 2 days) & 0.95 & 2.77 & Mean kg per adult equivalent eaten last 2 days \\
Fish consumption (in last 2 days) & 0.62 & 3.15 & Mean kg per adult equivalent eaten last 2 days \\
Livestock meat consumption (in last 2 days) & 0.50 & 2.29 & Mean kg per adult equivalent eaten last 2 days \\
Price of bushmeat & 8.23 & 1.42 & Mean Bolivianos per kg \\
Price of fish & 7.44 & 1.46 & Mean Bolivianos per kg \\
Price of livestock meat & 12.79 & 1.24 & Mean Bolivianos per kg \\
Household size & 4.03 & 1.86 & Mean number of adult equivalents in household \\
Income & 25.17 & 3.93 & Mean Bolivianos earned per adult equivalent in last two weeks \\
Wealth & 485.82 & 1.90 & Mean value of assets owned per adult equivalent in Bolivianos \\
Distance & 24.77 & 3.03 & Mean distance to nearest commercial town in km \\
Median age & 34.40 & & Median age of adult men in household \\
Median education & 1.31 & & Median years of education of adult men in household \\
\end{tabular}

over twice the national rate of $2.1 \%$. We know that the carrying capacity of forests for people that rely on wildlife for food is, even under the most productive circumstances, unlikely to exceed one person per $\mathrm{km}^{2}$ (Robinson \& Bennett, 2000). If we assume that the Tsimane' population is $c .7,500$, then population density exceeds six people per $\mathrm{km}^{2}$. This suggests that wild-

Table 2 Results of multiple regression analyses of the influence of prices, income and wealth on meat consumption. All variables were transformed to natural logarithms prior to analysis. Control variables were household size, median years of education and age of adult men in the household, distance from village to town, and a dummy variable for village (see text for details).

\begin{tabular}{|c|c|c|c|}
\hline \multirow[b]{2}{*}{ Explanatory variable } & \multicolumn{3}{|c|}{ Dependent variable - meat consumption } \\
\hline & Game meat & Fish & Livestock meat \\
\hline Game meat price & $\begin{array}{l}\beta=-1.145 \\
t=-2.85 \\
P=\mathbf{0 . 0 0 5}\end{array}$ & $\begin{array}{l}\beta=-0.058 \\
t=-0.16 \\
P=0.870\end{array}$ & $\begin{array}{l}\beta=0.332 \\
t=0.44 \\
P=0.657\end{array}$ \\
\hline Fish price & $\begin{array}{l}\beta=1.464 \\
t=2.82 \\
P=\mathbf{0 . 0 0 5}\end{array}$ & $\begin{array}{l}\beta=-0.042 \\
t=-0.18 \\
P=0.859\end{array}$ & $\begin{array}{l}\beta=-0.331 \\
t=-0.69 \\
P=0.494\end{array}$ \\
\hline Livestock meat price & $\begin{array}{l}\beta=7.446 \\
t=5.45 \\
\boldsymbol{P}<\mathbf{0 . 0 0 1}\end{array}$ & $\begin{array}{l}\beta=1.336 \\
t=2.78 \\
P=\mathbf{0 . 0 0 6}\end{array}$ & $\begin{array}{l}\beta=-3.823 \\
t=-2.07 \\
P=\mathbf{0 . 0 4 1}\end{array}$ \\
\hline Income & $\begin{array}{l}\beta=-0.010 \\
t=-0.18 \\
P=0.854\end{array}$ & $\begin{array}{l}\beta=0.003 \\
t=0.07 \\
P=0.943\end{array}$ & $\begin{array}{l}\beta=-0.122 \\
t=-2.22 \\
P=\mathbf{0 . 0 2 9}\end{array}$ \\
\hline Wealth & $\begin{array}{l}\beta=0.061 \\
t=0.52 \\
P=0.603\end{array}$ & $\begin{array}{l}\beta=0.130 \\
t=1.11 \\
P=0.270\end{array}$ & $\begin{array}{l}\beta=0.026 \\
t=0.24 \\
P=0.809\end{array}$ \\
\hline$n$ & 285 & 297 & 169 \\
\hline $\mathrm{R}^{2}$ & 0.39 & 0.41 & 0.39 \\
\hline
\end{tabular}

life cannot sustainably supply the bulk of meat in the Tsimane' diet, and that increasingly consumption of beef, pork and chicken must substitute for game meat, if wildlife are to remain in the Tsimane' forests in the future.

The situation is even more striking in Africa, where the number of consumers has increased from 100 million in 1900 , to over 800 million in 2000, and is expected to reach 1.6 billion in less than 25 years. Habitat for wildlife in Africa has declined since 1900 and demand for meat has probably increased over 8-fold since that time. Given these combined factors, it is highly unlikely that wildlife production is sufficient today to provide the majority of African households with a significant portion of their animal protein, and wildlife populations are certainly not growing as rapidly as the demand for meat (Wilkie \& Carpenter, 1999; Barnes, 2002).

Human populations in tropical forests and demand for meat are increasing faster than forest wildlife populations can sustainably supply. Consumption of livestock must increase, relative to consumption of game meat, if demand for meat is to be fulfilled without depleting the forests of wildlife. It has been argued that persuading consumers of game meat to switch to eating the meat of livestock will be difficult if cultural preferences primarily determine consumption patterns and if prices play a minor role in consumption (ma Mbalele, 1978; Chardonnet et al., 1995; Njiforti, 1996; Trefon \& de Maret, 1999). The results of our study suggest that meat prices are important and that even relatively isolated consumers who live in close proximity to wildlife, such as the Tsimane', are sensitive to price changes when making decisions about meat consumption. As the price of game meat rises, Tsimane' curtail their consumption of wildlife. More importantly, the price of beef has a strong positive correlation with the consumption of 
game meat and fish, i.e. the higher the price of beef, the higher the consumption of game and fish.

These results suggest that lowering the price of beef will have strong, desirable effects on the consumption of wildlife and fish, both of which are prone to unsustainable harvesting. These results bolster preliminary findings from a study of four Amerindian groups in Bolivia and one in Honduras (Wilkie \& Godoy, 2001), and support the conclusions of studies in Cameroon (Tambi, 1996; Nzouango \& Willcox, 2001) and preliminary findings in Gabon (Nsame Effa, unpub. data).

Demonstrating that consumption of game meat is sensitive to the price of meat from livestock has policy ramifications for curbing or halting the unsustainable hunting of wildlife for food. Results strongly suggest that increasing consumer access to and reducing the price of livestock meat is likely to diminish demand for game meat and consequently reduce or halt unsustainable hunting of wildlife for food. To reduce the price of livestock, governments in developing nations may need to make greater public investment in primary and applied research and in extension services to encourage adoption of technologies that allow livestock to fulfill multiple simultaneous roles, i.e. savings, insurance, food and income. Such technologies will need to increase the productivity of meat and lower its price for consumers and at the same time must not have undesirable effects, such as increasing deforestation for development of grazing lands.

If agricultural research and extension are to help solve the bushmeat crisis, donors and developing nation governments must reverse the downward trend in agricultural research and development spending. Although the total number of agricultural sector researchers has increased, dependence on expatriates declined, and the educational levels of national researchers has risen in Africa and other developing regions of the world (Pardey et al., 1997), total spending on arable and livestock research and development has declined in most developing nations in the past 30 years (Anderson et al., 1994). This is in contrast to agricultural research spending in developed nations. Since 1960 this has, for example, doubled in relation to the size of the agricultural sector in the US, and risen almost four-fold in Australia (Pardey \& Alston, 1995).

\section{Acknowledgements}

We would like to thank Carlos Peres and an anonymous reviewer for their helpful and constructive comments. This study was financed by the Cultural Anthropology Program of the National Science Foundation, USA (SBR-9417570).

\section{References}

Anderson, J.R., Pardey, P.G. \& Roseboom, J. (1994) Sustaining growth in agriculture - a quantiative review of agricultural research investments. Agricultural Economics, 10, 107-123.

Añez, J. (1992) The Chimane experience in selling jatata. In Sustainable Harvest and Marketing of Rain Forest Products (eds M.J. Plotkin \& L. Famolare), pp. 197-198. Island Press, Washington DC, USA.

Barnes, R.F.W. (2002) The bushmeat boom and bust in West and Central Africa. Oryx, 36, 236-242.

Bodmer, R.E., Fang, T.G. \& Moya, I. (1988) Primates and ungulates: a comparison of susceptibility to hunting. Primate Conservation, 9, 79-83.

Bodmer, R.E., Eisenberg, J.F. \& Redford, K.H. (1997) Hunting and the likelihood of extinction of Amazonian mammals. Conservation Biology, 11, 460-466.

Bowen-Jones, E. (1998) The African Bushmeat Trade - A Recipe for Extinction. Unpublished Report. Ape Alliance/Fauna \& Flora International, Cambridge, UK.

Bowen-Jones, E. \& Pendry, S. (1999) The threat to primates and other mammals from the bushmeat trade in Africa, and how this threat could be diminished. Oryx, 33, 233-246.

Browning, E.K. \& Zupan, M.A. (1999) Microeconomic Theory and Applications. Addison Wesley Publishing, Reading, USA.

Castillo, F. (1988) Chimanes, Cambas Y Collas. Don Boston, La Paz, Bolivia.

Chapman, C.A. \& Chapman, L.J. (1997) Forest regeneration in logged and unlogged forests of Kibale National Park, Uganda. Biotropica, 29, 390-412.

Chardonnet, P. (1995) Faune sauvage africaine: la ressource oubliée. International Game Foundation, CIRAD-EMVT, Luxembourg.

Chardonnet, P., Fritz, H., Zorzi, N. \& Feron, E. (1995) Current importance of traditional hunting and major contrasts in wild meat consumption in sub-saharan Africa. In Integrating People and Wildlife for a Sustainable Future (eds J.A. Bissonette \& P.R. Krausman), pp. 304-307. The Wildlife Society, Bethesda, USA.

Chicchón, A. (1992) Chimane resource use and market involvement in the Beni Biosphere Reserve, Bolivia. PhD thesis, University of Florida, Gainesville, USA.

Dethier, M. (1995) Etude chasse. ECOFAC, Yaoundé, Cameroon.

Ellis, R. (1996) A taste for movement: an exploration of the social ethics of the Tsimanes of lowland Bolivia. PhD thesis, St Andrews University, St Andrews, UK.

Fa, J.E., Yuste, J.E.G. \& Castelo, R. (2000) Bushmeat markets on Bioko Island as a measure of hunting pressure. Conservation Biology, 14, 1602-1613.

Godoy, R.A. (2001) Indians, Markets, and Rain Forests: Theory, Methods, Analysis. Columbia University Press, New York, USA.

Government of Bolivia (1995) Censo Indigena del Oriente, Chaco y Amazonía. Secretaría de Asuntos Etnicos, de Genero y Generacionales, Ministry of Human Development, Government of Bolivia, La Paz, Bolivia.

Gullison, R.E. (1995) Conservation of tropical forests through the sustainable production of forest products: the case of mahogany (Swietenia macrophylla King) in the Chimanes Forest, Beni, Bolivia. PhD thesis, Princeton University, USA.

Hart, J.A., Katembo, M. \& Punga, K. (1996) Diet, prey selection and ecological relations of leopard and golden cat in the Ituri Forest, Zaire. African Journal of Ecology, 34, 364-379. 
Howard, A.F., Rice, R.E. \& Gullison, R.E. (1996) Simulated financial returns and selected environmental impacts from four alternative silvicultural prescriptions applied in the neotropics: a case study of the Chimanes Forest, Bolivia. Forest Ecology and Management, 89, 43-57.

Huanca, T. (2000) Tsimane' indigenous knowledge, swidden fallow management, and conservation. $\mathrm{PhD}$ thesis, University of Florida, Gainesville, USA.

James, W.P.T. \& Schofield, E.C. (1990) Human Energy Requirements: a Manual for Planners and Nutritionists. Oxford University Press, Oxford, UK.

Lehm, Z. (1991) Loma Santa: procesos de reducción, dispersión y reocupación del espacio de los indìgenas Mojeños. Unpublished report. Universidad de la Cordillera, La Paz, Bolivia.

ma Mbalele, M. (1978) Part of African culture. Unasylva, 29, 16-17.

Ngnegueu, P.R. \& Fotso, R.C. (1998) Chasse Villageoise et Consequences pour la Conservation de la Biodiversité dans la Reserve de Biosphere du Dja. ECOFAC, Yaoundé, Cameroon.

Njiforti, H.L. (1996) Preferences and present demand for bushmeat in northern Cameroon: some implications for wildlife conservation. Environmental Conservation, 23, 149-155.

Nordenskiold, E. (1924) The Ethnography of South America as seen from Mojos in Bolivia. Comparative Ethnographical Studies no. 3, Ethnographic Museum, Göteborg, Sweden.

Nzouango, D. \& Willcox, A.S. (2001) Bushmeat Extraction Survey within the Banyangi and Mbo Tribes in the Southwest Province of Cameroon. Unpublished report. Wildlife Conservation Society, Yaoundé, Cameroon.

Pardey, P.G. \& Alston, J.A. (1995) Revamping Agricultural RED. International Food Policy Research Institute, Washington DC, USA.

Pardey, P.G., Roseboom, J. \& Beintema, N.M. (1997) Investments in African agricultural research. World Development, 25, 409-423.

Peres, C.A. \& van Roosmalen, M. (2002) Primate frugivory in two species-rich neotropical forests: implications for the demography of large-seeded plants in overhunted areas. In Seed Dispersal and Frugivory: Ecology, Evolution and Conservation (eds D.J. Levey, W.R. Silva \& M. Galetti), pp. 407-421. CABI Publishing, New York, USA.

Piland, R.A. (1991) Traditional Chimane agriculture and its relation to soils of the Beni Biosphere Reserve, Bolivia. MA thesis, University of Florida, Gainesville, USA.

Redford, K.H. (1993) Hunting in neotropical forests: a subsidy from nature. In Tropical Forests, People and Food: Biocultural Interactions and Applications to Development (eds C.M. Hladik, A. Hladik, O.F. Linares, H. Pagezy, A. Semple \& M. Hadley), pp. 227-246. UNESCO, Paris, France.
Reyes-García, V. (2001) Indigenous people, ethnobotanical knowledge, and market integration: exploring relations. $\mathrm{PhD}$ thesis. University of Florida, Gainesville, USA.

Rice, R.E., Gullison, R.E. \& Reid, J.W. (1997) Can sustainable management save tropical forests? Scientific American, 276, $44-49$.

Riester, J. (1976) En busca de la loma santa. Los Amigos del Libro, La Paz, Bolivia.

Riester, J. (1993) Universo mítico de los Chimane. Talleres Gr ficos HISBOL, La Paz, Bolivia.

Rioja, G. (1992) The jatata project: the pilot experience of Chimane empowerment. In Sustainable Harvest and Marketing of Rain Forest Products (eds M.J. Plotkin \& L. Famolare), pp. 192-196. Island Press, Washington DC, USA.

Robinson, J.G. \& Bennett, E.L. (2000) Carrying capacity limits to sustainable hunting in tropical forests. In Hunting for Sustainability in Tropical Forests (eds J.G. Robinson \& E.L. Bennett), pp. 13-30. Columbia University Press, New York, USA

Robinson, J.G., Redford, K.H. \& Bennett, E.L. (1999) Wildlife harvest in logged tropical forest. Science, 284, 595-596.

Rose, A.L. (2001) Social change and social values in mitigating bushmeat commerce. In Hunting and Bushmeat Utilization in the African Rain Forest: Perspectives Toward a Blueprint for Conservation Action (eds M.I. Bakarr, G.A.B. da Fonseca, R.A. Mittermeier, A.B. Rylands \& K.W. Painemilla), pp. 59-74. Conservation International, Washington DC, USA.

Tambi, N.E. (1996) The dynamics of household beef consumption in Cameroon. Agricultural Economics, 14, 11-19.

Trefon, T. \& de Maret, P. (1999) Snack nature dans les villes d'Afrique Centrale. In L'Homme et la Forêt Tropicale (eds S. Bahuchet, D. Bley, H. Pagezy \& N. Vernazza-Licht), pp. 559-572. Editions de Bergier, Châteauneuf de Grasse, France.

Universiteit Utrecht (2002) http:/ / www.library.uu.nl/wesp/ populstat/Americas/boliviac.htm [accessed 5 August 2002]

Vice Ministry of Indigenous Affairs (1999) http://www.rds.org.bo/macpio/pios/chiman/ chimanframeset_eng.htm [accessed 21 August 2002].

Wilkie, D.S. \& Carpenter, J.F. (1999) Bushmeat hunting in the Congo Basin: an assessment of impacts and options for mitigation. Biodiversity and Conservation, 8, 927-955.

Wilkie, D.S. \& Godoy, R.A. (2000) Economics of bushmeat. Science, 287, 975-976.

Wilkie, D.S. \& Godoy, R.A. (2001) Income and price elasticities of bushmeat demand in lowland Amerindian societies. Conservation Biology, 15, 1-9.

Winterhalder, B. \& Lu, F. (1997) A forager-resource population ecology model and implications for indigenous conservation. Conservation Biology, 11, 1354-1364. 